\title{
A Brief Review of Path Loss Models for mmWave Channels
}

\author{
Nermin K.A. Hamdan ${ }^{1 *}$, Begüm Korunur Engiz ${ }^{2}$ \\ 1* Ondokuz Mayıs University, Faculty of Engineering, Departmant of Electrical and Electronic, Samsun, Turkey, (ORCID: 0000-0002-5347-2832), \\ eng.nermin.hamdan@gmail.com \\ 2 Ondokuz Mayıs University, Faculty of Engineering, Departmant of Electrical and Electronic, Samsun, Turkey, (ORCID: 0000-0002-3905-1791), \\ bkengiz@omu.edu.tr
}

(International Symposium on Multidisciplinary Studies and Innovative Technologies (ISMSIT) 2021 - 21-23 October 2021)

(DOI: $10.31590 /$ ejosat.1022696)

ATIF/REFERENCE: Hamdan, N. K. A. \& Korunur Engiz, B. (2021). A Brief Review of Path Loss Models for mmWave Channels. European Journal of Science and Technology, (29), 264-272.

\begin{abstract}
It is planned to use millimeter wave (mm-wave) communication in 5th Generation (5G) communication systems, as it allows high bandwidth and accordingly high speed data communication. Path loss is one of the most important factors affecting system performance in mm-wave communication. Therefore, path loss must be taken into account in order to create an efficient and reliable mm-wave communication system and to obtain high data rates. It is very important for 5G systems to accurately determine the propagation characteristics and path loss models of the mm-wave communication channel. Many methods have been proposed in the literature to predict path loss with high accuracy and precision in 5G systems. In this review, it is aimed to provide researchers a clear knowledge about path loss in 5G mm-wave communication systems. Papers published between 2018-2021 which based on machine learning, deep learning, neural networks and propagation measurement approach were presented, and the main results of researches related to main path loss models Close-in (CI), and Alpha, Beta, Gamma (ABG) or Floating Intercept (FI) and papers that discussed 3-D ray tracing method were summarized in clear and precise manner.
\end{abstract}

Keywords: mmWave, 5G, Path loss models, Propagation measurements.

\section{mm-Dalga Kanallarındaki Yol Kaybı Modelleri Üzerine Kısa Bir Derleme}

$\ddot{\mathbf{O z}}$

Yüksek bant genişliğine ve buna bağlı olarak yüksek hızlı veri iletişimine olanak tanıması nedeniyle milimetre dalga (mm-dalga) haberleşmesinin 5. Nesil (5G) haberleşme sistemlerinde kullanılması planlanmaktadır. Yol kaybı, mm-dalga haberleşmesinde sistem başarımını etkileyen en önemli faktörlerden biridir. Bu nedenle etkin ve güvenilir mm-dalga haberleşme sistemini oluşturmak, yüksek veri hızları elde etmek için yol kaybı dikkate alınmalıdır. mm-dalga haberleşme kanalının yayılım özelliklerinin ve yol kaybı modellerinin doğru bir biçimde belirlenmesi $5 \mathrm{G}$ sistemleri için oldukça önemlidir. 5G sistemlerininde, yol kaybını yüksek doğruluk ve hassasiyetle tahmin etmek için literatürde birçok yöntem önerilmiştir. Bu derleme çalışmasında araştırmacılara, 5G mm-dalga haberleşme sistemlerinde yol kaybı hakkında bilgi sağlamak hedeflenmiştir. 2018-2021 yılları arasında yapılmış, makine öğrenmesi, derin öğrenme, sinir ağları ve yayılım ölçümü yaklaşımına dayanan birçok çalışma sunulmuş, CI, ABG veya FI gibi temel yol kaybı modellerini, 5G'de üç boyutlu ışın izleme yöntemlerini inceleyen çalışmalar açık ve anlaşılır bir biçimde özetlenmiştir.

Anahtar Kelimeler: mm-dalga, 5. Nesil, Yol kaybı modelleri, Yayılım ölçümleri.

* Corresponding Author: eng.nermin.hamdan@gmail.com 


\section{Introduction}

Wireless communication technology has changed the way we communicate and socialize in a remarkable way since its inception. It helped us to transmit data and information over a distance without any wires or cables. Also, the ability to communicate with people on move has developed arrestingly. Wireless communication has experienced different generations of technology starting from $0 \mathrm{G}$ to $5 \mathrm{G}$ (fifth generation). The target of $5 \mathrm{G}$ is to improve the scalability, connectivity, security, data rate and efficiency of the network [1, 2]. As the development of technology, the demands of the users are increasing. So, more bandwidth should be granted to satisfy the demand of users.

Millimeter wave (mmWave) frequencies (i.e., the frequency range of $3 \mathrm{GHz}$ to $300 \mathrm{GHz}$ ) are expected to be used in $5 \mathrm{G}$ networks. The unused mmWave spectrum provides an excellent chance to excess mobile broadband capacity, thereby providing better quality of service to users. However, according to a number of studies, mmWave frequencies have implementation issues, particularly with regards to path loss due to multiple factors, such as obstacles in the environment, weather condition, and atmosphere. Therefore, to find the best position of $5 \mathrm{G}$ base stations, investigation of the path loss model at these $5 \mathrm{G}$ mmWave frequencies is of crucial importance $[3,4]$. Surveys on mmWave $[5,6]$ have discussed propagation features, different channel models, parameters that affect system such as mediums, and operating frequency, and [7] for indoor environments have provided a general review of the radio propagation research at mmWave.

There are three basic models of path loss in 5G include Close-in Free Space with Reference Distance (CI), and Alpha, Beta, Gamma (ABG) or Floating Intercept (FI) [8, 9]. These models were built based on the traditional statistical approaches. However, data-dependent machine learning methods has also used for path loss predictions recently. In [10] path loss estimation was done through machine learning, and metrics used to compare the performances of random forest, artificial neural network, support vector regression forest models. [11] compares traditional channel models with a channel model obtained through deep learning techniques using satellite images supported by a simple path loss model for $2.6 \mathrm{GHz}$ mobile communication systems.

In [12] a novel method for modeling mmWave path losses was presented (Convolutional Neural Network, CNN). A new CNN structruce was proposed and it's superior performance over empirical models and deterministic models was shown [12]. Path loss predictions in urban areas were performed using the tabular data and images for machine learning models as two diverse types of inputs [13]. In [14] the path loss was predicted at different frequencies ranged $0.8 \mathrm{GHz}$ to $70 \mathrm{GHz}$ for urban and suburban environment, and in non-line of sight (NLOS) scenario. The proposed path loss model based on a deep neural network was shown to provide improved mean square error and higher prediction accuracy compared to the multi-frequency ABG path loss model.

A deep learning approach was applied in [15] for path loss modeling in urban environments for $5 \mathrm{G}$ systems, and proposes a combined method of the log-distance path loss model and a deep-learning-based model. Based on the simulation results the proposed path loss model outperforms the conventional models in the $3.5 \mathrm{GHz}$ frequency band. In [16] a new path loss model has been proposed for $5 \mathrm{G}$ communication in suburban settings using deep learning with advanced convolution and attention. From the experimental results, it was shown that the proposed attention-augmenting convolutional neural network performed better in test scenarios than modern empirical and deterministic methods in terms of the root mean square error.

In this study, we focused on the studies on path loss models in different environments and frequencies. A brief information about path loss models for wireless communications is given, and comparisons of models are presented under various measurement scenarios (indoor, outdoor) and frequencies.

\section{Material and Method}

\subsection{Methodology}

To determine the studies included in this review, some inclusion criteria were defined and the articles published between 2018 and 2021 were concerned. Some basic and mostly cited papers were also included. Search process was shortened to three academic databases as shown in Table 1. The articles most relevant to the study, and highly cited were selected from among a large number of articles.

Table 1. Search Tools.

\begin{tabular}{l|c}
\hline $\begin{array}{l}\text { Academic } \\
\text { database }\end{array}$ & URL address \\
\hline $\begin{array}{l}\text { Google } \\
\text { Scholar }\end{array}$ & https://scholar.google.com/ \\
\hline IEEE Explore & https://ieeexplore.ieee.org/Xplore/home.jsp \\
\hline Web of & https://apps.webofknowledge.com \\
Science & \\
\hline
\end{tabular}

\subsubsection{Related Work}

In [8] The properties of $5 \mathrm{G}$ radio communication systems were specified and propagation parameters, channel models, path losses in large areas and penetration losses in buildings were modeled by various standardization bodies and compared in the range 0.5 to $100 \mathrm{GHz}$. Additionaly, the various models suggestted by several independent groups based on extensive measurements and ray-tracing methods were compared. The details and applications of channel simulation software (NYUSIM) which helps generate realistic spatial and temporal channel responses was given in [17], channel spatial modeling for $5 \mathrm{G}$ mmWave was simulated for various mmWave bands (28, 38,60 , and $73 \mathrm{GHz}$ and channel model parameters like received power, path loss exponent and path loss for the specified frequencies were estimated using NYUSIM [18]. A statistical channel modelling was also simulated in [19] for urban microcell simulated in LOS condition at $28 \mathrm{GHz}$ operating frequency using NYUSIM, and best direction was determined according to parameters like path loss, path loss exponent and standard deviation. 
In view of the high path loss [20] focus on studying mmWave frequencies, that allow mmWave to scale to highdensity deployments and to consistently achieve high data rates. Also, in [21] the author discusses the fundamental characteristics of mmWave and two basic channel modeling methods to investigate the channel characteristics at mmWave bands. In [22] the author also focuses on how one can achieve less path loss through studying the impact of transmitter antenna height on the signal propagation.

In $[23,24]$ the authors conducted the experiment at 26,32 , and $39 \mathrm{GHz}$ frequency bands in line of sight (LOS) indoor conditions. The measurement was carried out for two antenna configurations obtaining a constant referred to the free space path loss (FSPL) condition for each band. Then a comparison between regression fitting and mmWave models were made. It inferred at $39 \mathrm{GHz}$ a higher path loss was acquired for the horn configuration, also path loss $3 \mathrm{~dB}$ difference between frequencies. Another study proposes a new frequency attenuation (FA) path loss model. In this model, ultra-wideband measurements are made for various frequencies in the 10-40 $\mathrm{GHz}$ in an outdoor environment for LOS scenarios, also in this study the three basic path loss models and FA path loss model are compared for single-frequency and multi-frequency schemes [25]. In the paper presented in [26] CI and FI models in indoor LOS/NLOS condition were applied. Further, using the same measurement parameters the 2-ray model is inspected for 40 $\mathrm{GHz}$ band. Also, it inferred path loss exponent (PLE) for CI and FI models for both scenarios are identical at $40 \mathrm{GHz}$.

In [27], the authors presented a directional horn and omnidirectional antenna used at the transmitter and receiver, respectively. Also, according to the acquired measurement data, the path loss was examined at 19, 28 and $38 \mathrm{GHz}$. At these frequencies, the path loss exponent is low and in NLOS channel the propagation signal was strong with a low delay. In [28] the authors examine the band of 5, 31and $90 \mathrm{GHz}$ under different channel condition and antenna CI and FI model were used to compare path loss simulation results (ray-tracing simulations) and measurement data. It deduced for LOS and NLOS conditions, CI model slopes show the difference between raytracing and measurements for slope is less than 0.3 and 0.6 respectively.

In another paper [29] the authors have made their study in the band of $38 \mathrm{GHz}$ in both LOS/NLOS conditions. Measurements were performed using a directional horn antenna, then based on the comparison of CI and FI path loss models they suggest that CI model is more suitable in the outdoor semicorridor environment then FI model. Another measurement method was used in [30] within the band of $18 \mathrm{GHz}$. By using a horn antenna radiation, the omnidirectional path loss synthesis has been confirmed, then in the measured data, the dual slope (DS) and CI path loss models were structured. Through these measurements they inferred that DS model is more suitable in the indoor corridors environment as compared to CI model.

The approach in [31] has relied on using a directional horn and omnidirectional antenna at the transmitter and receiver. Measurements were conducted, respectively for 3 scenarios, direct toward wall and toward window in the band of 28 and 38 $\mathrm{GHz}$ to study the basic path loss models. It concluded that the modified CI model is simpler than the models compared to the FI and ABG model. Also, for the PLE there is no big difference between the models. In [32] outdoor LOS/NLOS measurements were performed at five different mmWave frequencies and a new path loss model was proposed. They also suggest that a communication link can be build up in 20 and $30 \mathrm{GHz}$ bands using the prosed model for certain TX-RX separation distance. Furthermore in [33] authors have conducted the study in the band of 26, 28, 36, and $38 \mathrm{GHz}$. The experiment has studied the path loss model FI and CI in both LOS/NLOS. The result show that CI provides better performance than FI model.

The band of 26, 28, 32 and $38 \mathrm{GHz}$ in the scenario of indoor (emergency stairwell) were analyzed in [34] for single and multi-frequency; physical-anchor stair (PAS) and FI, ABG and close-in model with frequency-weighted path loss exponent (CIF) model were used, respectively. It concluded that in the emergency stairwell FI model is not that much beneficial compared to the proposed PAS model. Similarly, at single and multi-frequency, CI, FI, ABG and CIF path loss model are used in [35] to examine two different propagation mediums (stairwell), and the result provided can be helpful to understand the radio propagation in the studied environment. Also, in [36] measurements are performed in an indoor corridor and stairwell at $26 \mathrm{GHz}$ and $38 \mathrm{GHz}$. An omnidirectional and directional horn antenna were used at the transmitter and receiver, respectively. Path loss exponents are analyzed with respect to LOS/NLOS scenarios, co-polarization and cross-polarization and frequencies. It is reported that the directional PLEs are greater than omnidirectional PLEs. Also, PLEs for NLOS are greater than LOS and PLEs for stairwell are larger than that for corridor.

In [37] the author, discussed the characterization of $28 \mathrm{GHz}$ by using the computer simulation for the indoor office environment. Through analyzing the path loss model parameters, it shown that in the indoor environment many multipath waves were received in the LOS environment. Furthermore in [38] the author discussed the characteristics of $60 \mathrm{GHz}$ based on the method of shooting and bouncing ray tracing/image method (SBR/IM) in LOS/ NLOS scenarios. According to the results, PLE in LOS environments vary between 1.56 and 1.78 while 3.87 in NLOS. In [39] CI, FI, and CIF path loss models were used to study the received signal in the condition of LOS indoor stairwell. It reported that the models used, fit the measured data well in the band of 3.5 and $28 \mathrm{GHz}$ with the path loss exponent are found near to the FSPL. The band of 14 and $22 \mathrm{GHz}$ were analyzed in [40] that the authors made a measurement for different heights of TX and RX antenna for two path loss model. It concluded that the proposed dual slope path loss model is more outclass in all measurement scenarios compared to CI. Also, the same band and scenarios were reported in [41] but using different path loss model that it inferred in all scenarios the ABG model show a good foretelling of path loss.

In [42] the basic frequency attenuation (FA) and CIF models were used to evaluate the path loss in bands of 19, 28 and 38 $\mathrm{GHz}$. It concludes that the PLE for all the studied models are smaller than the ones for free space path loss exponent (FSPLE). A study of [43] applied the measurements at $38 \mathrm{GHz}$ for two different antenna polarization scenarios, and FI and CI models were used to study the action of path loss at the studied frequency. Through the measurement CI showed a good result in both LOS and NLOS while FI give a good result just in the LOS. A new approach in [44] was applied to study path loss in the band of $26 \mathrm{GHz}$ for two scenarios, and the authors deduce that path loss difference of LOS and obstructed LOS is about $5 \mathrm{~dB}$. In addition to the basic path loss models a new approach was reported in [45] to examine both of loss due to high frequency 
and edge shadow in the band of 3.5 and $28 \mathrm{GHz}$. The authors concluded that at the both bands in the studied scenarios, single and multi-frequency FI and ABG models show a good execution for path loss, and also PLE is less than FSPLE. In different antenna polarization, for directional and omnidirectional, CI, FI, $\mathrm{ABG}$ and a proposed path loss model were applied in [46] to examine the effect of path loss in the band of 4.5, 28 and 38 GHz. According to the results the proposed model had showed an average progress compared to the basic path loss models.

In [47] a new technique, the 3-D ray tracing method was applied to study the path loss of wave propagation. According to the measurement and simulation the new proposed method had shown more agreement with it compared to the other. In [48] the author presents an outdoor/ indoor environment at $60 \mathrm{GHz}$ by using the method of Smart Cognitive 3D Ray Tracer. It was shown that as the separation between the transmitter and the receiver increase, the mmWave's propagation attenuation increase. Also, obstacles in the path of waves cause reflection and diffraction that can increase the path loss. In [49] the author presented a new path loss model as 3GPP and mmMAGIC. According to the experiment and measurement after calibration, the path loss mean absolute error for LOS and NLOS decreased. Also, the use of machine learning algorithms reduces the mean absolute errors of path loss in both LOS/ NLOS. Furthermore in [50] the author presents a performance analysis method of mmWave cellular network based on 3-D Poisson point process (PPP) model, and analyses the impact of path loss and other parameters. It shows that the performance of 3-D PPP model is very accurate in the urban environment.

In order to be able to easily examine and compare the articles given in this study, the important details of the studies are summarized and given in Table 2 .

Table 2. Comparative evaluations of related works

\begin{tabular}{|c|c|c|c|c|c|c|}
\hline Frequency & $\begin{array}{c}\text { Indoor/Outdo } \\
\text { or }\end{array}$ & LOS/NLOS & Methodologies & Model & $\begin{array}{c}\text { Important } \\
\text { Results }\end{array}$ & Ref. \\
\hline $\begin{array}{c}26,39 \mathrm{GHz} \\
/ \\
26,32 \text { and } \\
39 \mathrm{GHz}\end{array}$ & Indoor & LOS & $\begin{array}{l}\text { two antenna } \\
\text { configurations, } \\
\text { comparison between } \\
\text { regression fitting and } \\
\text { mmWave models }\end{array}$ & $\begin{array}{l}\text { CI, FI path } \\
\text { loss models } \\
\text { and mm } \\
\text { Wave model. }\end{array}$ & $\begin{array}{c}\text { At } 39 \mathrm{GHz} \text { a } \\
\text { higher PL was } \\
\text { acquired for the } \\
\text { horn } \\
\text { configuration, } \\
\text { also pathloss } \\
\text { 3dB difference } \\
\text { between } \\
\text { frequencies }\end{array}$ & {$[23]-[24]$} \\
\hline $\begin{array}{l}40 \mathrm{GHz} / \\
5,31 \text { and } \\
90 \mathrm{GHz}\end{array}$ & Indoor & Both & $\begin{array}{l}\text { CI and FI models are } \\
\text { used and the 2-ray } \\
\text { model is inspected } \\
\text { for } 40 \mathrm{GHz} \text { band / } \\
\text { Comparison between } \\
\text { CI, FI models and } \\
\text { ray-tracing } \\
\text { simulations under } \\
\text { different channel } \\
\text { condition and } \\
\text { antenna. }\end{array}$ & $\begin{array}{c}\text { CI, FI path } \\
\text { loss model } \\
\text { and two-ray } \\
\text { model / } \\
\text { CI and FI } \\
\text { path loss } \\
\text { model }\end{array}$ & $\begin{array}{l}\text { PLE for CI and } \\
\text { FI models for } \\
\text { LOS, NLOS are } \\
\text { identical / } \\
\text { LOS, NLOS } \\
\text { conditions, CI } \\
\text { model slopes } \\
\text { show the } \\
\text { difference } \\
\text { between ray- } \\
\text { tracing and } \\
\text { measurements }\end{array}$ & [26]-[28] \\
\hline $\begin{array}{c}19,28 \text { and } \\
38 \mathrm{GHz}\end{array}$ & $\begin{array}{l}\text { Indoor to } \\
\text { Outdoor }\end{array}$ & NLOS & $\begin{array}{l}\text { A directional horn } \\
\text { and omnidirectional } \\
\text { antenna were used on } \\
\text { transmitter and } \\
\text { receiver, respectively. } \\
\text { Also, according to the } \\
\text { acquired } \\
\text { measurement data, } \\
\text { path loss was } \\
\text { examined. } \\
\end{array}$ & $\begin{array}{c}\text { CI, ABG } \\
\text { path loss } \\
\text { model }\end{array}$ & $\begin{array}{l}\text { The path loss } \\
\text { exponent is low } \\
\text { and in NLOS } \\
\text { channel the } \\
\text { propagation } \\
\text { signal was } \\
\text { strong with a } \\
\text { low delay. }\end{array}$ & [27] \\
\hline $38 \mathrm{GHz}$ & $\begin{array}{l}\text { Outdoor } \\
\text { (semi- } \\
\text { corridor) }\end{array}$ & Both & $\begin{array}{l}\text { A measurement of a } \\
\text { directional horn } \\
\text { antenna was } \\
\text { performed, then }\end{array}$ & $\begin{array}{l}\text { CI and FI } \\
\text { path loss } \\
\text { model }\end{array}$ & $\begin{array}{l}\text { Compared to FI } \\
\text { model, CI } \\
\text { model is more } \\
\text { appropriate for }\end{array}$ & [29] \\
\hline
\end{tabular}




\begin{tabular}{|c|c|c|c|c|c|c|}
\hline & & & $\begin{array}{c}\text { based on a } \\
\text { comparison of these } \\
\text { measurement } \\
\text { between the CI and } \\
\text { FI path loss models } \\
\text { were extract the } \\
\text { result. }\end{array}$ & & $\begin{array}{l}\text { the outdoor } \\
\text { environment }\end{array}$ & \\
\hline $18 \mathrm{GHz}$ & Indoor & LOS & $\begin{array}{c}\text { By using a horn } \\
\text { antenna radiation, the } \\
\text { omnidirectional path } \\
\text { loss synthesis has } \\
\text { been confirmed, then } \\
\text { in the measured data, } \\
\text { the DS and CI path } \\
\text { loss model were } \\
\text { structured. }\end{array}$ & $\begin{array}{l}\text { CI and DS } \\
\text { path loss } \\
\text { model }\end{array}$ & $\begin{array}{l}\text { Compared to the } \\
\text { CI model, the } \\
\text { DS model is } \\
\text { better suited to } \\
\text { interior } \\
\text { corridors }\end{array}$ & {$[30]$} \\
\hline $\begin{array}{c}28 \text { and } 38 \\
\mathrm{GHz}\end{array}$ & $\begin{array}{l}\text { Indoor (dining } \\
\text { room) }\end{array}$ & LOS & $\begin{array}{l}\text { A directional horn } \\
\text { and an } \\
\text { omnidirectional } \\
\text { antenna were used on } \\
\text { the transmitter and } \\
\text { receiver, respectively } \\
\text { for } 3 \text { scenarios, and } \\
\text { single and multi-band } \\
\text { basic path loss } \\
\text { models were studied. }\end{array}$ & $\begin{array}{c}\text { The } \\
\text { proposed } \\
\text { and the CI, } \\
\text { FI and ABG } \\
\text { path loss } \\
\text { model }\end{array}$ & $\begin{array}{c}\text { The M-CI } \\
\text { model compared } \\
\text { to the FI and } \\
\text { ABG model is } \\
\text { simpler. There is } \\
\text { no big } \\
\text { difference for } \\
\text { PLE between } \\
\text { the models. }\end{array}$ & [31] \\
\hline $\begin{array}{c}26,28,36 \\
\text { and } 38 \\
\mathrm{GHz}\end{array}$ & Outdoor & Both & $\begin{array}{c}\text { A measurement for a } \\
\text { different scenario for } \\
20 \text { and } 30 \mathrm{GHz} \text { bands } \\
\text { were taken to } \\
\text { compare the proposed } \\
\text { model with the basic } \\
\text { path loss models. }\end{array}$ & $\begin{array}{l}\text { Proposed } \\
\text { model and } \\
\text { CI, FI and } \\
\text { ABG path } \\
\text { loss model }\end{array}$ & $\begin{array}{c}\text { A } \\
\text { communication } \\
\text { link can be } \\
\text { established } \\
\text { using prosed } \\
\text { model for } \\
\text { certain TX-RX } \\
\text { separation }\end{array}$ & [32] \\
\hline $\begin{array}{c}26,28,32 \\
\text { and } 38 \\
\mathrm{GHz}\end{array}$ & $\begin{array}{c}\text { Indoor } \\
\text { (emergency } \\
\text { stairwell) / } \\
\text { Indoor } \\
\text { (stairwell) / }\end{array}$ & LOS & $\begin{array}{c}\text { Single and } \\
\text { multifrequency }\end{array}$ & $\begin{array}{l}\text { FI, ABG, } \\
\text { FAS and CIF } \\
\text { path loss } \\
\text { models / } \\
\text { The basic } \\
\text { path loss } \\
\text { model and } \\
\text { CIF }\end{array}$ & $\begin{array}{l}\text { FI model is not } \\
\text { that much } \\
\text { beneficial } \\
\text { compared to the } \\
\text { PAS / } \\
\text { Measurement } \\
\text { data is helpful to } \\
\text { understand } \\
\text { propagation } \\
\text { mechanism in } \\
\text { the studied } \\
\text { medium }\end{array}$ & {$[34]-[35]$} \\
\hline $\begin{array}{c}26 \text { and } 38 \\
\mathrm{GHz}\end{array}$ & $\begin{array}{c}\text { Indoor } \\
\text { corridor and } \\
\text { stairwell }\end{array}$ & Both & $\begin{array}{l}\text { An omnidirectional } \\
\text { biconical as } \\
\text { transmitter and a } \\
\text { steerable } \\
\text { directional horn as } \\
\text { receiver used for both } \\
\text { co-polarization, } \\
\text { cross-polarization } \\
\text { LOS/NLOS } \\
\text { measurement } \\
\text { scenarios }\end{array}$ & $\begin{array}{l}\text { CI model in } \\
\text { V-V } \\
\text { polarization, } \\
\text { CIX model } \\
\text { in V-H }\end{array}$ & $\begin{array}{l}\text { Omnidirectional } \\
\text { PLEs } \\
\text { are smaller than } \\
\text { directional PLEs }\end{array}$ & {$[36]$} \\
\hline $\begin{array}{c}3.5 \text { and } 28 \\
\mathrm{GHz}\end{array}$ & $\begin{array}{c}\text { Indoor } \\
\text { (stairwell) }\end{array}$ & LOS & $\begin{array}{l}\text { CI, FI, and CIF path } \\
\text { loss models were } \\
\text { used to study the } \\
\text { received signal in the } \\
\text { stairwell according to } \\
\text { the measured data }\end{array}$ & $\begin{array}{l}\text { CI, FI and } \\
\text { CIF path } \\
\text { loss model }\end{array}$ & $\begin{array}{l}\text { The models that } \\
\text { used fit the } \\
\text { measured data } \\
\text { well, path loss } \\
\text { exponent are } \\
\text { close to FSPL. }\end{array}$ & [39] \\
\hline
\end{tabular}




\begin{tabular}{|c|c|c|c|c|c|c|}
\hline $\begin{array}{c}14 \text { and } 22 \\
\mathrm{GHz}\end{array}$ & Indoor & Both & $\begin{array}{l}\text { A measurement in the } \\
\text { band of } 14 \text { and } 22 \\
\text { GHz for different } \\
\text { heights of TX and } \\
\text { RX antenna were } \\
\text { examined for } \\
\text { two/multi frequency } \\
\text { path loss model. }\end{array}$ & $\begin{array}{c}\text { CI and } \\
\text { proposed } \\
\text { dual slope } \\
\text { (DS) path } \\
\text { loss model / } \\
\text { DS and ABG } \\
\text { path loss } \\
\text { model }\end{array}$ & $\begin{array}{c}\text { Dual slope path } \\
\text { loss model is } \\
\text { better than CI / } \\
\text { ABG model } \\
\text { shows a good } \\
\text { foretelling of } \\
\text { path loss at } 14 \\
\text { and } 22 \mathrm{GHz} \text { and } \\
\text { DS needs less } \\
\text { modeling } \\
\text { parameters }\end{array}$ & [40]-[41] \\
\hline $\begin{array}{c}19,28 \text { and } \\
38 \mathrm{GHz}\end{array}$ & Indoor & Both & $\begin{array}{l}\text { The basic path loss } \\
\text { model, FA and CIF } \\
\text { models were used to } \\
\text { study path loss in } \\
\text { bands of } 19,28 \text { and } \\
38 \mathrm{GHz}\end{array}$ & $\begin{array}{l}\text { CIF, FA and } \\
\text { the basic } \\
\text { path loss } \\
\text { model }\end{array}$ & $\begin{array}{l}\text { The PLE are } \\
\text { smaller for all } \\
\text { the studied } \\
\text { models } \\
\text { compared to the } \\
\text { FSPLE }\end{array}$ & [42] \\
\hline $38 \mathrm{GHz}$ & Outdoor & Both & $\begin{array}{c}\text { In two different } \\
\text { antenna polarization } \\
\text { scenarios the basic } \\
\text { path loss model, FI } \\
\text { and CI models were } \\
\text { used to study the } \\
\text { action of path loss at } \\
38 \mathrm{GHz}\end{array}$ & $\begin{array}{c}\mathrm{FI} \text { and } \mathrm{CI} \\
\text { model }\end{array}$ & $\begin{array}{l}\text { Through the } \\
\text { measurement CI } \\
\text { showed a good } \\
\text { result in both } \\
\text { LOS and NLOS } \\
\text { while FI give a } \\
\text { good result just } \\
\text { in the LOS. }\end{array}$ & [43] \\
\hline $26 \mathrm{GHz}$ & Indoor(office) & $\begin{array}{l}\text { LOS and } \\
\text { OLOS }\end{array}$ & $\begin{array}{l}\text { FI and CI model were } \\
\text { implemented in the } \\
\text { frequency band of } \\
26 \mathrm{GHz} \text { that they } \\
\text { made a measurement } \\
\text { through the MMSE } \\
\text { approach to derived } \\
\text { the parameters of the } \\
\text { models }\end{array}$ & $\begin{array}{c}\text { FI and CI } \\
\text { model }\end{array}$ & $\begin{array}{l}\text { Through the } \\
\text { results, they } \\
\text { deduce that } \\
\text { between LOS } \\
\text { and OLOS } \\
\text { theirs path loss } \\
\text { difference about } \\
5 \mathrm{~dB}\end{array}$ & [44] \\
\hline $\begin{array}{l}3.5 \text { and } 28 \\
\mathrm{GHz} / \\
4.5,28 \text { and } \\
38 \mathrm{GHz}\end{array}$ & Indoor & Both & $\begin{array}{l}\text { Single and multi- } \\
\text { frequency, CI, FI, } \\
\text { ABG and CIF path } \\
\text { loss models / } \\
\text { For different antenna } \\
\text { polarization CI, FI, } \\
\text { ABG and proposed } \\
\text { path loss models }\end{array}$ & $\begin{array}{l}\text { FI, CI, ABG } \\
\text { and CIF } \\
\text { model / } \\
\text { The CI, FI } \\
\text { and ABG } \\
\text { and } \\
\text { proposed } \\
\text { path loss } \\
\text { model }\end{array}$ & $\begin{array}{c}\text { At the both } \\
\text { bands single and } \\
\text { multi-frequency } \\
\text { FI and ABG } \\
\text { models show a } \\
\text { good execution, } \\
\text { PLE is less than } \\
\text { the FSPLE / } \\
\text { the proposed } \\
\text { model yielded } \\
\text { an average } \\
\text { improvement } \\
\text { compared to the } \\
\text { basic path loss } \\
\text { models }\end{array}$ & [45]-[46] \\
\hline $28 \mathrm{GHz}$ & Indoor & Both & $\begin{array}{l}\text { Using a new } \\
\text { technique, the 3-D } \\
\text { ray tracing method to } \\
\text { study the path loss of } \\
\text { wave propagation }\end{array}$ & $\begin{array}{l}\text { 3-D ray } \\
\text { tracing } \\
\text { method }\end{array}$ & $\begin{array}{l}\text { According to } \\
\text { the } \\
\text { measurement } \\
\text { and simulation } \\
\text { the new } \\
\text { proposed } \\
\text { method had } \\
\text { shown more } \\
\text { agreement with } \\
\text { it compared to } \\
\text { the other. }\end{array}$ & [47] \\
\hline
\end{tabular}




\section{Conclusions and Recommendations}

In this review, we present the studies that examine the performance of various path loss models at candidate mmWave frequencies for $5 \mathrm{G}$ wireless communication systems. We have discussed the three basic path loss models CI, FI, ABG, and some other path loss models that have been derived by modifying the values of these three basic models. Furthermore, the studies that cover different measurements scenarios such as, LOS/NLOS, or both, indoor/outdoor at different frequencies 5, $3.5,4.5,14,18,19,22,26,28,31,32,36,38,39,40,90 \mathrm{GHz}$ were included.

Even though some paper investigates the same frequency band, their models or method were different. Additionally, the studies that uses data dependent machine learning methods or neural network to predict path loss were also presented. Finally, we presented a clear knowledge about path loss models in 5G to the readers, that we briefly summarized the main results of each studied papers. This provides the opportunities for researchers to modify the previous pathloss models and propose new pathloss models, that can be more beneficial compared to the previous ones

\section{References}

[1] Adachi, F. (2002, October). Evolution towards broadband wireless systems. In The 5th International Symposium on Wireless Personal Multimedia Communications (Vol. 1, pp. 19-26). IEEE.

[2] Osseiran, A., Boccardi, F., Braun, V., Kusume, K., Marsch, P., Maternia, M., et al. (2014). Scenarios for $5 \mathrm{G}$ mobile and wireless communications: the vision of the METIS project. IEEE communications magazine, 52(5), 26-35.

[3] Narekar, N. P., \& Bhalerao, D. M. (2015, April). A survey on obstacles for $5 \mathrm{G}$ communication. In 2015 International Conference on Communications and Signal Processing (ICCSP) (pp. 0831-0835). IEEE.

[4] Mitra, R. N., \& Agrawal, D. P. (2015). 5G mobile technology: A survey. ICT express, 1(3), 132-137.

[5] Niu, Y., Li, Y., Jin, D., Su, L., \& Vasilakos, A. V. (2015). A survey of millimeter wave communications (mmWave) for 5G: opportunities and challenges. Wireless networks, 21(8), 2657-2676.

[6] Uwaechia, A. N., \& Mahyuddin, N. M. (2020). A comprehensive survey on millimeter wave communications for fifth-generation wireless networks: Feasibility and challenges. IEEE Access, 8, 6236762414.

[7] Al-Saman, A., Cheffena, M., Elijah, O., Al-Gumaei, Y. A., Abdul Rahim, S. K., \& Al-Hadhrami, T. (2021). Survey of millimeter-wave propagation measurements and models in indoor environments. Electronics, 10(14), 1653.

[8] Rappaport, T. S., Xing, Y., MacCartney, G. R., Molisch, A. F., Mellios, E., \& Zhang, J. (2017). Overview of millimeter wave communications for fifthgeneration (5G) wireless networks - With a focus on propagation models. IEEE Transactions on antennas and propagation, 65(12), 6213-6230.

[9] Sun, S., Rappaport, T. S., Rangan, S., Thomas, T. A., Ghosh, A., Kovacs, I. Z., et al. (2016, May).
Propagation path loss models for 5G urban micro-and macro-cellular scenarios. In 2016 IEEE 83rd Vehicular Technology Conference (VTC Spring) (pp. 1-6). IEEE.

[10]Zhang, Y., Wen, J., Yang, G., He, Z., \& Wang, J. (2019). Path loss prediction based on machine learning: Principle, method, and data expansion. Applied Sciences, 9(9), 1908.

[11] Thrane, J., Zibar, D., \& Christiansen, H. L. (2020). Model-aided deep learning method for path loss prediction in mobile communication systems at 2.6 GHz. Ieee Access, 8, 7925-7936.

[12] Cheng, H., Ma, S., \& Lee, H. (2020). CNN-based mmWave path loss modeling for fixed wireless access in suburban scenarios. IEEE Antennas and Wireless Propagation Letters, 19(10), 1694-1698.

[13] Sotiroudis, S. P., Sarigiannidis, P., Goudos, S. K., \& Siakavara, K. (2021). Fusing diverse input modalities for path loss prediction: A deep learning approach. IEEE Access, 9, 30441-30451.

[14] Nguyen, C., \& Cheema, A. A. (2021). A Deep Neural Network-Based Multi-Frequency Path Loss Prediction Model from $0.8 \mathrm{GHz}$ to $70 \mathrm{GHz}$. Sensors, 21(15), 5100.

[15] Juang, R. T. (2021). Explainable Deep-Learning-Based Path Loss Prediction from Path Profiles in Urban Environments. Applied Sciences, 11(15), 6690.

[16]Cheng, H., Ma, S., Lee, H., \& Cho, M. (2021). Millimeter Wave Path Loss Modeling for 5G Communications Using Deep Learning With Dilated Convolution and Attention. IEEE Access, 9, 6286762879.

[17] Sun, S., MacCartney, G. R., \& Rappaport, T. S. (2017, May). A novel millimeter-wave channel simulator and applications for $5 \mathrm{G}$ wireless communications. In 2017 IEEE International Conference on Communications (ICC) (pp. 1-7). IEEE.

[18]Hasan, R., Mowla, M. M., Rashid, M. A., Hosain, M. K., \& Ahmad, I. (2019, February). A statistical analysis of channel modeling for $5 \mathrm{~g}$ mmwave communications. In 2019 International Conference on Electrical, Computer and Communication Engineering (ECCE) (pp. 1-6). IEEE.

[19]Lodro, M. M., Majeed, N., Khuwaja, A. A., Sodhro, A. H., \& Greedy, S. (2018, March). Statistical channel modelling of $5 \mathrm{G}$ mmWave MIMO wireless communication. In 2018 International Conference on Computing, Mathematics and Engineering Technologies (iCoMET) (pp. 1-5). IEEE.

[20] Fiandrino, C., Assasa, H., Casari, P., \& Widmer, J. (2019). Scaling millimeter-wave networks to dense deployments and dynamic environments. Proceedings of the IEEE, 107(4), 732-745.

[21]Lin, Z., Du, X., Chen, H. H., Ai, B., Chen, Z., \& Wu, D. (2019). Millimeter-wave propagation modeling and measurements for $5 \mathrm{G}$ mobile networks. IEEE Wireless Communications, 26(1), 72-77.

[22] Saba, N., Mela, L., Sheikh, M. U., Ruttik, K., Salo, J., \& Jäntti, R. (2021, April). Measurements at 5G Commercial $26 \mathrm{GHz}$ Frequency with Above and on Rooftop Level Antenna Masts in Urban Environment. In 2021 IEEE 93rd Vehicular Technology Conference (VTC2021-Spring) (pp. 1-5). IEEE. 
[23] Pimienta-del-Valle, D., Mendo, L., Riera, J. M., \& Garcia-del-Pino, P. (2020). Indoor LOS Propagation Measurements and Modeling at 26, 32, and $39 \mathrm{GHz}$ Millimeter-Wave Frequency Bands. Electronics, 9(11), 1867.

[24] Pimienta-del-Valle, D., Hernández-Sáenz, S., SáizCoronado, P., Mendo, L., Garcia-del-Pino, P., \& Riera, J. M. (2019, March). Indoor path loss measurements at the $5 \mathrm{G}$ millimeter-wave bands of 26 and $39 \mathrm{GHz}$. In 2019 13th European Conference on Antennas and Propagation (EuCAP) (pp. 1-5). IEEE.

[25] Al-Samman, A. M., Rahman, T. A., Azmi, M. H., \& Hindia, M. N. (2016). Large-scale path loss models and time dispersion in an outdoor line-of-sight environment for $5 \mathrm{G}$ wireless communications. AEU-International Journal of Electronics and Communications, 70(11), 1515-1521.

[26] Al-Samman, A. M., Rahman, T. A., Azmi, M. H., Sharaf, A., Yamada, Y., \& Alhammadi, A. (2018, March). Path loss model in indoor environment at 40 $\mathrm{GHz}$ for 5G wireless network. In 2018 IEEE 14th International Colloquium on Signal Processing \& Its Applications (CSPA) (pp. 7-12). IEEE.

[27] Al-Samman, A. M., Azmi, M. H., Al-Gumaei, Y. A., Al-Hadhrami, T., Fazea, Y., \& Al-Mqdashi, A. (2020). Millimeter wave propagation measurements and characteristics for 5G system. Applied Sciences, 10(1), 335.

[28] Liu, J., Matolak, D. W., Mohsen, M., \& Chen, J. (2019, September). Path loss modeling and ray-tracing verification for 5/31/90 GHz indoor channels. In 2019 IEEE 90th Vehicular Technology Conference (VTC2019-Fall) (pp. 1-6). IEEE.

[29] Qamar, F., Siddiqui, M. H. S., Hindia, M. N., Dimyati, K., Abd Rahman, T., \& Talip, M. S. A. (2018, November). Propagation Channel Measurement at 38 $\mathrm{GHz}$ for $5 \mathrm{G}$ mm-wave communication Network. In 2018 IEEE student conference on research and development (SCOReD) (pp. 1-6). IEEE.

[30] Oyie, N. O., \& Afullo, T. J. O. (2018, August). An Empirical Approach to Omnidirectional Path Loss and Line-of-sight Probability Models at $18 \mathrm{GHz}$ for $5 \mathrm{G}$ Networks. In 2018 Progress in Electromagnetics Research Symposium (PIERS-Toyama) (pp. 129-136). IEEE.

[31] Al-Samman, A. M., Rahman, T. A., Azmi, M. H., \& Al-Gailani, S. A. (2018). Millimeter-wave propagation measurements and models at $28 \mathrm{GHz}$ and $38 \mathrm{GHz}$ in a dining room for $5 \mathrm{G}$ wireless networks. Measurement, 130, 71-81.

[32] Hindia, M. N., Al-Samman, A. M., Rahman, T. A., \& Yazdani, T. M. (2018). Outdoor large-scale path loss characterization in an urban environment at 26, 28, 36, and $38 \mathrm{GHz}$. Physical Communication, 27, 150-160.

[33] Qamar, F., Hindia, M. N., Abd Rahman, T., Hassan, R., Dimyati, K., \& Nguyen, Q. N. (2021). Propagation characterization and analysis for $5 \mathrm{G}$ mmWave through field experiments. CMC-COMPUTERS MATERIALS \& CONTINUA, 68(2), 2249-2264.

[34] Al-Samman, A. M., Abd Rahman, T., HINDIA, M. N., \& Nasir, J. (2018). Path loss model for indoor emergency stairwell environment at millimeter wave band for 5G network. Turkish Journal of Electrical Engineering \& Computer Sciences, 26(6), 3024-3032.

[35] Aldhaibani, A. O., Rahman, T. A., \& Alwarafy, A. (2020). Radio-propagation measurements and modeling in indoor stairwells at millimeter-wave bands. Physical Communication, 38, 100955.

[36] Shen, Y., Shao, Y., Xi, L., Zhang, H., \& Zhang, J. (2021). Millimeter-Wave Propagation Measurement and Modeling in Indoor Corridor and Stairwell at 26 and $38 \mathrm{GHz}$. IEEE Access, 9, 87792-87805.

[37] Nagatomo, S., \& Omiya, M. (2021, January). Prediction of $28 \mathrm{GHz}$ Propagation Characteristics in an Indoor Office Environment Based on Large-scale Computer Simulations. In 2020 International Symposium on Antennas and Propagation (ISAP) (pp. 311-312). IEEE.

[38]Li, S., Liu, Y., Lin, L., Sun, D., Yang, S., \& Sun, X. (2018, March). Simulation and modeling of millimeterwave channel at $60 \mathrm{GHz}$ in indoor environment for $5 \mathrm{G}$ wireless communication system. In 2018 IEEE International Conference on Computational Electromagnetics (ICCEM) (pp. 1-3). IEEE.

[39] Al-Saman, A., Mohamed, M., \& Cheffena, M. (2020). Radio propagation measurements in the indoor stairwell environment at 3.5 and $28 \mathrm{GHz}$ for $5 \mathrm{G}$ wireless networks. International Journal of Antennas and Propagation, 2020.

[40] Oyie, N. O., \& Afullo, T. J. (2018). Measurements and analysis of large-scale path loss model at 14 and 22 $\mathrm{GHz}$ in indoor corridor. IEEE Access, 6, 17205-17214.

[41] Oyie, N. O., \& Afullo, T. J. O. (2018, August). A Comparative Study of Dual-Slope Path Loss Model in Various Indoor Environments at 14 to $22 \mathrm{GHz}$. In 2018 Progress in Electromagnetics Research Symposium (PIERS-Toyama) (pp. 121-128). IEEE.

[42] Al-Samman, A. M., Abd Rahman, T., \& Azmi, M. H. (2018). Indoor corridor wideband radio propagation measurements and channel models for $5 \mathrm{~g}$ millimeter wave wireless communications at $19 \mathrm{GHz}, 28 \mathrm{GHz}$, and $38 \mathrm{GHz}$ bands. Wireless Communications and Mobile Computing, 2018.

[43] Qamar, F., Hindia, M. H. D., Dimyati, K., Noordin, K. A., Majed, M. B., Abd Rahman, T., \& Amiri, I. S. (2019). Investigation of future 5G-IoT millimeter-wave network performance at $38 \mathrm{GHz}$ for urban microcell outdoor environment. Electronics, 8(5), 495.

[44] Rubio, L., Torres, R. P., Rodrigo Peñarrocha, V. M., Pérez, J. R., Fernández, H., Molina-Garcia-Pardo, J. M., \& Reig, J. (2019). Contribution to the channel path loss and time-dispersion characterization in an office environment at $26 \mathrm{GHz}$. Electronics, 8(11), 1261.

[45] Al-Samman, A. M., Al-Hadhrami, T., Daho, A., Hindia, M. H. D., Azmi, M. H., Dimyati, K., \& Alazab, M. (2019). Comparative study of indoor propagation model below and above $6 \mathrm{GHz}$ for $5 \mathrm{G}$ wireless networks. Electronics, 8(1), 44.

[46] Majed, M. B., Rahman, T. A., Aziz, O. A., Hindia, M. N., \& Hanafi, E. (2018). Channel characterization and path loss modeling in indoor environment at 4.5, 28, and $38 \mathrm{GHz}$ for $5 \mathrm{G}$ cellular networks. International Journal of Antennas and Propagation, 2018.

[47] Hossain, F., Geok, T. K., Rahman, T. A., Hindia, M. N., Dimyati, K., Ahmed, S., ... \& Abd Rahman, N. Z. 
(2019). An efficient 3-D ray tracing method: prediction of indoor radio propagation at $28 \mathrm{GHz}$ in $5 \mathrm{G}$ network. Electronics, 8(3), 286.

[48] Kamboh, U. R., Ullah, U., Khalid, S., Raza, U., Chakraborty, C., \& Al-Turjman, F. (2021). Path loss modelling at $60 \mathrm{GHz}$ mmWave based on cognitive 3D ray tracing algorithm in 5G. Peer-to-Peer Networking and Applications, 1-17.

[49] Sousa, M., Alves, A., Vieira, P., Queluz, M. P., \& Rodrigues, A. (2021). Analysis and Optimization of 5G Coverage Predictions Using a Beamforming Antenna Model and Real Drive Test Measurements. IEEE Access, 9, 101787-101808.

[50]Xu, T., Pan, Z., Zhang, H., Zou, Q., \& Bao, C. (2021, June). Modeling and Analysis of Millimeter Wave 5G Cellular Networks Based on 3-D Spatial Model. In Journal of Physics: Conference Series (Vol. 1944, No. 1, p. 012025). IOP Publishing. 